\title{
Influence of fungicides and vesicular arbuscular mycorrhiza on growth and nutrient balance of soybean by used DRIS equation
}

\author{
Dalshad A. Darwesh ${ }^{1^{*}}$, Kadija K. Mustafa ${ }^{2}$ \\ ${ }^{1}$ Department of Environmental Sciences, College of Science, University of Salahaddin, Hawler, Iraq; \\ *Corresponding Author: dadaziz06@yahoo.co.uk \\ ${ }^{2}$ Department of Biology, College of Science Education, University of Salahaddin, Hawler, Iraq
}

Received 13 June 2012; revised 20 July 2012; accepted 1 August 2012

\begin{abstract}
A pot experiment was conducted to study the effect of mycorrhiza, fungicides in difference concentration and there combination on growth and nutrients balance index of soya bean. Tow AM treatments including with and with out mycorrhiza and tow fungicides (parasmid and antarcol) each of them including four concentration $\left(0.0,0.25,0.5\right.$ and $1 \mathrm{~kg} \cdot$ donum $\left.^{-1}\right)$ were tested in factorial completely randomized design in the three replication. The results indicates that the higher value of total dry matter weight was recorded from combination treatment $\left(F_{1} M_{1} C_{1}\right)$ which attained $11.09 \mathrm{gm} \cdot$ pot $^{-1}$, while the lower value $2.25 \mathrm{gm} \cdot$ pot $^{-1}$ was produced by combination treatment $\left(\mathrm{F}_{2} \mathrm{M}_{2} \mathrm{C}_{3}\right)$, however the same combination treatments was showed that the nitrogen, phosphorus, magnesium and iron in the shoot tissues in the mycorrhizal plant with lower concentration of fungicides were significantly greater $(P<0.01)$ compared to control and higher concentration treatments. The higher concentration of the above mentioned nutrients (28.33, $8.36,6.34 \mathrm{mg} \cdot \mathrm{g}^{-1}, 251.00 \mathrm{mg} \cdot \mathrm{Kg}^{-1}$ ) was recorded. The result of nutrient index and nutrient balance index revealed that the lower NBI (56.18) was recorded in combination treatments $\left(F_{1} M_{1} C_{1}\right)$, while the higher NBI (2033.81) was produced from combination treatments $\left(\mathrm{F}_{2} \mathrm{M}_{2} \mathrm{C}_{3}\right)$, moreover the results shows significant negative correlation ship between NBI and total dry matter weight $\left(r=-0.63^{*}\right)$.
\end{abstract}

Keywords: VA-Mycorrhiza; DRIS; Nutrients Balance Index

\section{INTRODUCTION}

Mycorrhizal symbioses are essential components of approximately $80 \%$ of plant systems, and the beneficial role that mycorrhizal fungi play in agricultural production is well recognized [1]. Although the use of pesticides, herbicides and fungicides is fundamental for cultivation, there is now a growing body of evidence of their effects and impact on plant growth and on microorganisms such as mycorrhizal fungi [2,3]. Systemic fungicides applied to soil around plants can be absorbed by roots and translocated to other parts of the plant. These kinds of fungicides are persistent in the plant and their action on mycorrhizal fungi can either be against their vegetative or their reproduction structures [4]. Benomyl is among the most frequently used systemic fungicides against pathogenic fungi of cereals and oil seed plants [5]. It has been found to negatively affect mycorrhizal symbioses by delaying or preventing the formation of AM symbiosis between fungi and roots and by decreasing plant P-uptake [6]. Benomyl suppresses mycelial growth by preventing nuclear division. In fact, this fungicide inhibits mitosis by blocking the formation of microtubules when chromosomes are separated. Combined use of multiple types of fungicide can amplify the negative effects on mycorrhiza. When the soil was treated with the two fungicides in combination, mycorrhiza did not appear at all on the roots. This demonstrates that fungicides used against different soil borne pathogens can have significant side effects on mycorrhiza in soil, the extent of which may be dependent on the type of fungicide [7]. The results of [8] show that benomyl inhibited fungal activity of both internal and external hyphae at the low application level $\left(1 \mathrm{mg} \cdot \mathrm{g}^{-1}\right.$ soil) corresponding to the recommended field dose. Propiconazole decreased the activity of the external hyphae at the low application level $\left(0.21 \mathrm{mg} \cdot \mathrm{g}^{-1}\right.$ soil $)$ but did not affect the internal activity at any application level. Treating seeds with different chemicals such as fungicides to ensure their higher germination is a common practice before planting [9]. However such treatments may influence soil microbial population including arbascular mycorrhizal fungi 
developing a beneficial symbiosis association with most of the terrestrial plants including crops plants. Consideration of the actions and interaction between plants and soil microorganisms including arbascular mycorrhiza, influenced by different parameters such as chemicals in the field can be very useful for the development of favorable strategies, which can enhance the efficiency of agricultural production although using different chemical including fungicides may effect AM activities, which are of great significance for the production and health of ecosystems [7]. Accordingly, it can very pertinent to evaluate how different fungicides may effect the activities of VM in the soil and how AM can interactively adjust the unfavorable effect of fungicides on soil microbial population. This is because AM have some very great abilities, including alleviating the effects of different soil stresses on plant growth [10], and also controlling the adverse effects of soil pathogens [11]. Soy bean is one of the most important legume crops for human nutrition and has been traditionally cultivated in saline soils in arid and semi-arid regions, the agronomical importance of soybean (Glycine max L.) is linked to its high protein content $(25 \%-29 \%)$ [12]. Diagnosis and Recommendation Integrated System (DRIS) is a method to evaluate a plant nutritional status that uses a comparison of the leaf tissue nutrient concentration ratio of the nutrient pairs with norms from a high yielding treatment. The first step to implement DRIS or any other foliar diagnostic system is the establishment of the standard values or norms ,thus the DRIS norms and their standard deviation and coefficient of variance for $\mathrm{N}$, $\mathrm{P}, \mathrm{Ca}, \mathrm{Mg}, \mathrm{K}, \mathrm{Fe}$, and total dry matter ratio were calculated from the high yielding treatments, that is to say DRIS norms were established locally depending on the nutrient concentration and their ratio from the high yielding plants (treatment) from these different set of conditions are similar. After the establishment of DRIS norms, we calculate the index of each nutrient that ranges from negative to positive values. The negative index values indicate that the nutrient levels are below the optimum. Consequently, the more negative index, the more deficient the nutrient, similarly a positive index indicates that the nutrient levels are above the optimum, and the more positive index the more excessive the nutrient that is relative to normal, and the DRIS index is equal to zero indicating that the nutrient is at optimum levels, but there are authors that do not consider a nutrient deficiency or excessive when the DRIS indices are negative or positives and near to zero [13]. The DRIS also computes an overall index, which is the sum of the absolute values of the nutrient index, called nutrient balance index, the smaller the absolute sum of al DRIS indices, the lesser the imbalance among nutrient. Little information exists on the effect of current soybean seed applied fungicides on colonization of vesicular arbuscular mycorrhiza in soy beans. Also the information on the effect of fungicide and mycorrhiza on nutrient balance by using the DRIS equation are rare. Thus the objects of this study are to evaluate the effect of some fungicides on mycorrhiza activities and yield of soybean, also to investigate the combination effect of fungicide and mycorrhiza on nutrient balance in soybean.

\section{MATERIALS AND METHODS}

The research was conducted in the green house of College of Science Education, University of Salahaddin/ Erbil. The experiment was a factorial on the basis of completely randomized design including two factors and three replication the first factors involved AM treatment and without AM treatment, the second factors was two fungicides (Brasamid and Antracol) including four concentration $\left(0.0,0.25,0.5\right.$ and $1 \mathrm{~kg} \cdot$ donum $\left.^{-1}\right)$ and their combination on growth, nutrient status and nutrient balance in soybean. Hence 16 experimental treatments were tested in each replicates making the total of 48 pots .The soil was dispensed in to plastic pots ( $7 \mathrm{~kg}$ soil per pots) the $5 \mathrm{gm}$ of vesicular arbuscular mycorrhizal inoculum were distributed and the sterilized soy bean seeds (6 seeds) were planted in each pots after germination thinned to 4 plants. Plant irrigated with tap water to maintain soil moisture near field capacity by using weight method. Leaf samples were collected as described by [14] and washed thoroughly with dilute acid $(0.2 \mathrm{~N} \mathrm{HCl})$ and pure water to remove residues. The samples were dried at $65^{\circ} \mathrm{C}$ and then wet digested in $\mathrm{H}_{2} \mathrm{O}_{2}$ and $\mathrm{H}_{2} \mathrm{SO}_{4}$ acid $(1 / 1, \mathrm{v} / \mathrm{v})$ mixture [15]. The $\mathrm{N}$ content was measured by the microKjeldahl digestion method of [16], the $\mathrm{P}$ content was determined by the molybdenum blue colorimetric method of [17], $\mathrm{Ca}, \mathrm{Mg}$ and Fe were determined by atomic absorption, the flame photometric method of [18] was used to determined $\mathrm{K}$. The plants were harvested before flowering stage and oven dry to obtain total dry weight.

\subsection{Soil Properties}

Some physical and chemical characteristics of the soil under study were as follows: texture: sandy loam; $\mathrm{CaCO}_{3}$ $150 \mathrm{~g} \cdot \mathrm{kg}^{-1}$; pH (saturated paste) 7.7 ; EC $0.6 \mathrm{dS} \cdot \mathrm{m}^{-1}$; organic matter $1.7 \mathrm{gm} \cdot \mathrm{kg}^{-1}, \mathrm{NH}_{4} \mathrm{OA}_{\mathrm{c}}$-extractable $\mathrm{K} 1.49$ meq $\cdot 100 \mathrm{~g}^{-1}$; exchangeable $\mathrm{Ca} 11.0 \mathrm{meq} \cdot 100 \mathrm{~g}^{-1} ; \mathrm{Mg} 5$ meq $100 \mathrm{~g}^{-1}$; total $\mathrm{N} 0.44 \mathrm{mg} \cdot \mathrm{kg}^{-1} ; \mathrm{NaHCO}_{3}$-extractable P $5.6 \mathrm{mg} \cdot \mathrm{kg}^{-1}$ and DTPA-extractable Fe, as $0.009 \mathrm{mg} \cdot \mathrm{kg}^{-1}$, respectively. Chemical soil analysis was conducted as described in [19].

\subsection{Calculation of DRIS Indices}

The DRIS indices were calculated by using the following index equations by [20]: 


$$
\begin{aligned}
& N \text { Index }=\frac{f(N / P)+f(N / K)+f(N / C a)+f(N / M g)+f(N / F e)+f(N / D M)}{n} ; \\
& P \text { Index }=\frac{f(N / P)+f(N / K)+f(N / C a)+f(N / M g)+f(N / F e)+f(N / D M)}{n} ; \\
& K \text { Index }=\frac{-f(N / K)-f(P / K)+f(K / C a)+f(K / M g)+f(K / F e)+f(K / D M)}{n} ; \\
& \text { Ca Index }=\frac{-f(N / C a)-f(P / C a)-f(K / C a)+f(C a / M g)+f(C a / F e)+f(C a / D M)}{n} ; \\
& \text { Mg Index }=\frac{-f(N / M g)-f(P / M g)-f(K / M g)-f(C a / M g)+f(M g / F e)+f(M g / D M)}{n} ; \\
& \text { Fe Index }=\frac{-f(N / F e)-f(P / F e)-f(K / F e)-f(C a / F e)-f(M g / F e)+f(F e / D M)}{n} ; \\
& \text { DM Index }=\frac{-f(N / D M)-f(P / D M)-f(K / D M)-f(C a / D M)-f(M g / D M)-f(F e / D M)}{n} .
\end{aligned}
$$

$$
\begin{aligned}
& \mathrm{f}(\mathrm{X} / \mathrm{Y})=(\mathrm{X} / \mathrm{Y} / \mathrm{x} / \mathrm{y}-1) * 100 \mathrm{k} / \mathrm{CV}_{\mathrm{x} / \mathrm{y}} \text { if } \mathrm{X} / \mathrm{Y} \geq \mathrm{x} / \mathrm{y} \\
& \mathrm{f}(\mathrm{X} / \mathrm{Y})=(1-\mathrm{x} / \mathrm{y} / \mathrm{X} / \mathrm{Y}) * 100 \mathrm{k} / \mathrm{CV}_{\mathrm{x} / \mathrm{y}} \text { if } \mathrm{x} / \mathrm{y} \geq \mathrm{X} / \mathrm{Y}
\end{aligned}
$$

$\mathrm{X}$ and $\mathrm{Y}=$ nutrients (N: nitrogen, $\mathrm{P}$ : phosphorus: potassium, Mg: magnesium, Ca: calcium, Fe: iron);

$\mathrm{N}=$ number of ratios;

$\mathrm{x} / \mathrm{y}$ mean for $\mathrm{X} / \mathrm{Y}$, in reference population (high-yielding treatment, Norm).

$\mathrm{CV}_{(\mathrm{x} / \mathrm{y})}=$ coefficient of variation for $\mathrm{x} / \mathrm{y}$, in reference population (high-yielding group).

$\mathrm{K}=$ sensitivity coefficient (1).

\subsection{Statistical Analysis}

The experiment was designed in completely randomized design with 3 replications (factorial CRD). The experimental data were analyzed by ANOVA and differences between the treatment means were separated by Adj.LSD Test [21].

\section{RESULTS}

The effects of fungicides applications in different concentration on plant growth of mycorrhizal and nonmycorrhizal plants are presented in Tables 1-4. Plant colonized by mycorrhiza grow well and were significantly larger $(\mathrm{P}<0.01)$ than non inoculated .The higher value of total dry matter weight was recorded from combination treatment $\left(\mathrm{F}_{1} \mathrm{M}_{1} \mathrm{C}_{1}\right)$ which attained $11.09 \mathrm{gm} \cdot \mathrm{pot}^{-1}$, while the lower value $2.25 \mathrm{gm} \cdot \mathrm{pot}^{-1}$ was produced by combination treatment $\left(\mathrm{F}_{2} \mathrm{M}_{2} \mathrm{C}_{3}\right)$. This stimulatory effect of VA mycorrhiza on total dry matter weight was maintained with application lower concentration of both fungicides. In contrast the higher concentration of fungicides de- creased the plant growth compared to control .However the higher concentration of $\mathrm{F}_{2}$ Antracol significantly depressed the total dry weight in comparison with $F_{1}$ Prasamid concentration in both mycorrhizal and nonmycorrhizal plants as shown in (Table 4). The higher total dry matter weight $\left(8.43 \mathrm{gm} \cdot\right.$ pot $\left.^{-1}\right)$ was recorded in case application of $0.25 \mathrm{~kg} \cdot \mathrm{donum}^{-1}$ fungicides, whereas the lower value $4.01 \mathrm{gm} \cdot \mathrm{pot}^{-1}$ was recorded in treatment $\mathrm{C}_{3}$ which include the application of $1 \mathrm{~kg} \cdot$ donum $^{-1}$ of fungicides, the total dry matter of plants was not significantly affected by both fungicides, but in general the Prasamid give higher dry matter than those treated by Antracol. Soybean shoot treated or not with mycorrhiza and difference concentration of fungicides are given in Tables 1-4. The nitrogen, phosphorus, magnesium and iron in the shoot tissues in the mycorrhizal plant with lower concentration of fungicides were significantly greater $(\mathrm{P}<0.01)$ compared to control and higher concentration treatments. The higher concentration of the above mentioned nutrients $\left(28.33,8.36,6.34 \mathrm{mg} \cdot \mathrm{g}^{-1}\right.$, $251.00 \mathrm{mg} \cdot \mathrm{Kg}^{-1}$ ) was recorded in the factorial treatment $\left(\mathrm{F}_{1} \mathrm{M}_{1} \mathrm{C}_{1}\right)$. The application both fungicides with or without mycorrhiza had no significant effect on the $\mathrm{Ca}^{2+}$ and $\mathrm{K}^{+}$content in shoot. Fungicide addition in different concentration significantly decrease the nitrogen, phosphorus, magnesium and iron contents of shoot, except $\mathrm{Ca}^{2+}$ and $\mathrm{K}^{+}$not effect by fungicides and their concentration. The higher concentration of above nutrient was recorded in case of application of $\left(0.25 \mathrm{~kg} \cdot \mathrm{donum}^{-1}\right)$ fungicides.

The results that are presented in Table 5 show the significant effect of mycorrhiza, fungicides, concentration of fungicides and their combination on nutrient index and nutrient balance index in soybean. The lower NBI (56.18) 
Table 1. Combination effect of mycorrhiza, fungicides and their concentration on total dry weight and nutrient content of soya bean.

\begin{tabular}{|c|c|c|c|c|c|c|c|}
\hline \multirow{2}{*}{ Treatments } & \multicolumn{6}{|c|}{ Nutrients concentration } & \multirow{2}{*}{$\begin{array}{c}\text { Total dry } \\
\text { weight } \\
\text { (gm/pot) }\end{array}$} \\
\hline & $\begin{array}{l}\text { Nitrogen } \\
(\mathrm{mg} / \mathrm{gm})\end{array}$ & $\begin{array}{l}\text { Phosphorus } \\
\text { (mg/gm) }\end{array}$ & $\begin{array}{l}\text { Calcium } \\
\text { (mg/gm) }\end{array}$ & $\begin{array}{l}\text { Magnesium } \\
(\mathrm{mg} / \mathrm{gm})\end{array}$ & $\begin{array}{l}\text { Potassium } \\
(\mathrm{mg} / \mathrm{gm})\end{array}$ & $\begin{array}{c}\text { Iron } \\
(\mathrm{mg} / \mathrm{kg})\end{array}$ & \\
\hline $\mathrm{F}_{1} \mathrm{M}_{1} \mathrm{C}_{0}$ & 8.50 & 5.79 & 22.50 & 3.09 & 26.55 & 91.33 & 4.15 \\
\hline $\mathrm{F}_{1} \mathrm{M}_{1} \mathrm{C}_{1}$ & 28.33 & 8.36 & 35.33 & 6.34 & 16.94 & 251.00 & 11.09 \\
\hline $\mathrm{F}_{1} \mathrm{M}_{1} \mathrm{C}_{2}$ & 19.67 & 5.36 & 58.66 & 1.92 & 22.28 & 119.33 & 6.26 \\
\hline $\mathrm{F}_{1} \mathrm{M}_{1} \mathrm{C}_{3}$ & 18.00 & 5.17 & 33.00 & 2.27 & 23.35 & 115.00 & 5.11 \\
\hline $\mathrm{F}_{1} \mathrm{M}_{2} \mathrm{C}_{0}$ & 17.83 & 5.26 & 47.00 & 2.51 & 21.21 & 128.00 & 6.20 \\
\hline $\mathrm{F}_{1} \mathrm{M}_{2} \mathrm{C}_{1}$ & 16.66 & 5.51 & 23.66 & 3.67 & 18.01 & 119.00 & 7.28 \\
\hline $\mathrm{F}_{1} \mathrm{M}_{2} \mathrm{C}_{2}$ & 13.16 & 5.59 & 30.66 & 1.92 & 28.68 & 113.33 & 5.65 \\
\hline $\mathrm{F}_{1} \mathrm{M}_{2} \mathrm{C}_{3}$ & 15.50 & 5.26 & 35.33 & 2.27 & 22.28 & 71.00 & 3.29 \\
\hline $\mathrm{F}_{2} \mathrm{M}_{1} \mathrm{C}_{0}$ & 12.00 & 5.69 & 30.66 & 2.74 & 23.35 & 90.33 & 5.62 \\
\hline $\mathrm{F}_{2} \mathrm{M}_{1} \mathrm{C}_{1}$ & 22.55 & 7.28 & 40.00 & 4.51 & 22.28 & 151.33 & 7.35 \\
\hline $\mathrm{F}_{2} \mathrm{M}_{1} \mathrm{C}_{2}$ & 17.83 & 5.35 & 35.33 & 2.27 & 20.14 & 130.33 & 5.70 \\
\hline $\mathrm{F}_{2} \mathrm{M}_{1} \mathrm{C}_{3}$ & 16.66 & 4.52 & 40.00 & 2.51 & 27.61 & 121.00 & 5.39 \\
\hline $\mathrm{F}_{2} \mathrm{M}_{2} \mathrm{C}_{0}$ & 10.83 & 3.92 & 33.00 & 2.86 & 27.61 & 84.33 & 4.02 \\
\hline $\mathrm{F}_{2} \mathrm{M}_{2} \mathrm{C}_{1}$ & 8.50 & 4.30 & 35.33 & 2.74 & 19.08 & 124.33 & 8.02 \\
\hline $\mathrm{F}_{2} \mathrm{M}_{2} \mathrm{C}_{2}$ & 12.00 & 4.36 & 37.66 & 2.62 & 26.55 & 113.00 & 5.27 \\
\hline $\mathrm{F}_{2} \mathrm{M}_{2} \mathrm{C}_{3}$ & 7.33 & 3.46 & 35.33 & 2.39 & 22.28 & 55.67 & 2.25 \\
\hline Adj. LSD (1\%) & 9.31 & 3.48 & 5.86 & 16.15 & 1.96 & 52.24 & 2.25 \\
\hline
\end{tabular}

$\mathrm{M}_{1}=$ with mycorrhiza; $\mathrm{F}_{1}=$ Brasamid $\mathrm{F}_{2}=$ Antraco; $\mathrm{M}_{2}=$ without mycorrhiza; $\mathrm{C}_{0}=0 ; \mathrm{C}_{1}=0.25 \mathrm{Kg} \cdot \mathrm{donum}{ }^{-1} ; \mathrm{C}_{2}=0.5 \mathrm{~kg} \cdot \mathrm{donum}{ }^{-1} ; \mathrm{C}_{3}=1 \mathrm{~kg} \cdot \mathrm{donum}{ }^{-1}$.

Table 2. Effect of mycorrhiza inoculum on total dry weight and nutrients content of soya bean.

\begin{tabular}{|c|c|c|c|c|c|c|c|}
\hline \multirow{2}{*}{ Treatments } & \multicolumn{6}{|c|}{ Nutrients concentration } & \multirow{2}{*}{$\begin{array}{l}\text { Total dry } \\
\text { weight } \\
\text { (gm/pot) }\end{array}$} \\
\hline & $\begin{array}{l}\text { Nitrogen } \\
(\mathrm{mg} / \mathrm{gm})\end{array}$ & $\begin{array}{l}\text { Phosphorus } \\
\text { (mg/gm) }\end{array}$ & $\begin{array}{l}\text { Calcium } \\
(\mathrm{mg} / \mathrm{gm})\end{array}$ & $\begin{array}{l}\text { Magnesium } \\
(\mathrm{mg} / \mathrm{gm})\end{array}$ & $\begin{array}{l}\text { Potassium } \\
(\mathrm{mg} / \mathrm{gm})\end{array}$ & $\begin{array}{c}\text { Iron } \\
(\mathrm{mg} / \mathrm{kg})\end{array}$ & \\
\hline $\mathrm{M}_{1}$ & 17.95 & 8.91 & 36.94 & 3.20 & 22.82 & 131.71 & 6.33 \\
\hline $\mathrm{M}_{2}$ & 12.73 & 7.06 & 34.75 & 2.62 & 23.22 & 99.08 & 5.24 \\
\hline Adj. LSD (1\%) & 3.19 & 1.19 & 5.53 & 0.67 & 2.01 & 17.90 & 0.77 \\
\hline
\end{tabular}

Table 3. Effect of fungicides on total dry weight and nutrients content of soybean.

\begin{tabular}{|c|c|c|c|c|c|c|c|}
\hline \multirow{2}{*}{ Treatments } & \multicolumn{6}{|c|}{ Nutrients concentration } & \multirow{2}{*}{$\begin{array}{l}\text { Total dry } \\
\text { weight } \\
\text { (gm/pot) }\end{array}$} \\
\hline & $\begin{array}{l}\text { Nitrogen } \\
(\mathrm{mg} / \mathrm{gm})\end{array}$ & $\begin{array}{c}\text { Phosphorus } \\
\text { (mg/gm) }\end{array}$ & $\begin{array}{l}\text { Calcium } \\
(\mathrm{mg} / \mathrm{gm})\end{array}$ & $\begin{array}{l}\text { Magnesium } \\
(\mathrm{mg} / \mathrm{gm})\end{array}$ & $\begin{array}{c}\text { Potassium } \\
(\mathrm{mg} / \mathrm{gm})\end{array}$ & $\begin{array}{c}\text { Iron } \\
(\mathrm{mg} / \mathrm{kg})\end{array}$ & \\
\hline $\mathrm{F}_{1}$ & 17.21 & 8.68 & 35.77 & 3.20 & 22.42 & 124.00 & 6.13 \\
\hline $\mathrm{F}_{2}$ & 13.47 & 7.29 & 35.92 & 2.62 & 23.62 & 106.79 & 5.45 \\
\hline Adj. LSD (1\%) & 3.19 & 1.19 & 5.53 & 0.67 & 2.01 & 17.90 & 0.77 \\
\hline
\end{tabular}


Table 4. Effect of different concentration of fungicides on total dry weight and nutrients content of soybean.

\begin{tabular}{|c|c|c|c|c|c|c|c|}
\hline \multirow{2}{*}{ Treatments } & \multicolumn{6}{|c|}{ Nutrients concentration } & \multirow{2}{*}{$\begin{array}{l}\text { Total dry } \\
\text { weight } \\
\text { (gm/Pot) }\end{array}$} \\
\hline & $\begin{array}{l}\text { Nitrogen } \\
(\mathrm{mg} / \mathrm{gm})\end{array}$ & $\begin{array}{l}\text { Phosphorus } \\
\text { (mg/gm) }\end{array}$ & $\begin{array}{l}\text { Calcium } \\
(\mathrm{mg} / \mathrm{gm})\end{array}$ & $\begin{array}{l}\text { Magnesium } \\
(\mathrm{mg} / \mathrm{gm})\end{array}$ & $\begin{array}{c}\text { Potassium } \\
(\mathrm{mg} / \mathrm{gm})\end{array}$ & $\begin{array}{c}\text { Iron } \\
(\mathrm{mg} / \mathrm{kg})\end{array}$ & \\
\hline $\mathrm{C}_{0}$ & 12.29 & 7.75 & 33.29 & 2.80 & 24.68 & 96.50 & 4.99 \\
\hline $\mathrm{C}_{1}$ & 19.01 & 9.54 & 33.58 & 4.31 & 19.08 & 159.42 & 8.43 \\
\hline $\mathrm{C}_{2}$ & 15.67 & 7.75 & 40.58 & 2.18 & 24.42 & 117.00 & 5.72 \\
\hline $\mathrm{C}_{3}$ & 14.38 & 6.90 & 35.92 & 2.36 & 23.88 & 88.67 & 4.01 \\
\hline Adj. LSD (1\%) & 5.43 & 2.03 & 9.41 & 1.14 & 3.42 & 30.45 & 1.31 \\
\hline
\end{tabular}

Table 5. Combination effect of mycorrhiza, fungicide and their concentration on nutrient index and NBI of soybean.

\begin{tabular}{|c|c|c|c|c|c|c|c|c|c|}
\hline \multirow{2}{*}{ Treatments } & \multicolumn{7}{|c|}{ Nutrients Index } & \multirow[b]{2}{*}{ NBI } & \multirow[b]{2}{*}{ TDW (gm/pot) } \\
\hline & $\mathrm{N}$ Index & P Index & Ca Index & Mg Index & K Index & Fe Index & TDW Index & & \\
\hline $\mathrm{F}_{1} \mathrm{M}_{1} \mathrm{C}_{0}$ & -387.74 & 20.44 & -76.91 & 55.02 & 553.10 & -91.53 & -72.38 & 1257.13 & 4.15 \\
\hline $\mathrm{F}_{1} \mathrm{M}_{1} \mathrm{C}_{1}$ & -4.78 & -8.39 & -4.86 & 28.09 & -5.10 & -1.72 & -3.24 & 56.18 & 11.09 \\
\hline $\mathrm{F}_{1} \mathrm{M}_{1} \mathrm{C}_{2}$ & -95.27 & -12.04 & 121.88 & -30.52 & 158.15 & -92.37 & -49.83 & 560.05 & 6.26 \\
\hline $\mathrm{F}_{1} \mathrm{M}_{1} \mathrm{C}_{3}$ & 127.04 & 7.07 & -146.91 & -16.56 & 165.07 & -40.39 & -95.31 & 598.36 & 5.11 \\
\hline $\mathrm{F}_{1} \mathrm{M}_{2} \mathrm{C}_{0}$ & -85.03 & 1.51 & 118.81 & 2.28 & 166.15 & -166.87 & -36.86 & 577.51 & 6.20 \\
\hline $\mathrm{F}_{1} \mathrm{M}_{2} \mathrm{C}_{1}$ & 38.08 & 16.09 & -173.15 & -4.97 & 149.42 & -49.40 & 23.92 & 455.04 & 7.28 \\
\hline $\mathrm{F}_{1} \mathrm{M}_{2} \mathrm{C}_{2}$ & -196.06 & -9.55 & -65.35 & -35.94 & 362.09 & 2.26 & -57.45 & 728.70 & 5.65 \\
\hline $\mathrm{F}_{1} \mathrm{M}_{2} \mathrm{C}_{3}$ & -43.08 & 44.05 & 66.67 & 6.21 & 288.24 & -198.05 & -164.04 & 810.35 & 3.29 \\
\hline $\mathrm{F}_{2} \mathrm{M}_{1} \mathrm{C}_{0}$ & -195.35 & -55.84 & 14.11 & 31.96 & 338.22 & -111.90 & -21.20 & 768.57 & 5.62 \\
\hline $\mathrm{F}_{2} \mathrm{M}_{1} \mathrm{C}_{1}$ & -420.80 & -70.37 & 205.67 & 11.03 & 303.19 & -53.22 & 24.49 & 1088.77 & 7.35 \\
\hline $\mathrm{F}_{2} \mathrm{M}_{1} \mathrm{C}_{2}$ & -32.69 & -5.35 & -14.48 & -6.29 & 149.43 & -46.15 & -44.46 & 298.85 & 5.70 \\
\hline $\mathrm{F}_{2} \mathrm{M}_{1} \mathrm{C}_{3}$ & -154.26 & -62.08 & 11.42 & -6.12 & 270.14 & 30.04 & -89.15 & 623.22 & 5.39 \\
\hline $\mathrm{F}_{2} \mathrm{M}_{2} \mathrm{C}_{0}$ & -299.44 & -68.70 & 79.68 & 41.24 & 489.21 & -139.68 & -102.31 & 1220.27 & 4.02 \\
\hline $\mathrm{F}_{2} \mathrm{M}_{2} \mathrm{C}_{1}$ & -438.04 & -57.93 & 186.00 & 29.50 & 253.05 & -29.75 & 57.16 & 1051.42 & 8.02 \\
\hline $\mathrm{F}_{2} \mathrm{M}_{2} \mathrm{C}_{2}$ & -280.39 & -58.11 & 95.55 & 14.59 & 365.44 & -78.99 & -58.09 & 951.17 & 5.27 \\
\hline $\mathrm{F}_{2} \mathrm{M}_{2} \mathrm{C}_{3}$ & -511.02 & -57.62 & 377.42 & 75.34 & 564.15 & -216.96 & -231.31 & 2033.81 & 2.25 \\
\hline
\end{tabular}

was recorded in combination treatments $\left(\mathrm{F}_{1} \mathrm{M}_{1} \mathrm{C}_{1}\right)$. While the higher NBI (2033.81) was produced from combination treatments $\left(\mathrm{F}_{2} \mathrm{M}_{2} \mathrm{C}_{3}\right)$ also the nutrient index in the same table indicate that inoculation with mycorrhiza fungus changed the order of nutrients requirements in other word the presence of endophyte improved the balance of elements, as shown by the lowest sum of indices for the mycorrhiza soya bean. Thus the result revealed that the $\mathrm{N}$ index, $\mathrm{P}$ index, $\mathrm{Ca}$ index, $\mathrm{K}$ index $\mathrm{Fe}$ index and TDW index reduced from $(-85.03,1.51,118.81,166.15,36.86$ and -166.87$)$ in non-mycorrhizal plant to $(-4.78,-8.39$, $-4.86,-5.10,-1.72$ and -3.24$)$ in mycorrhizal plant, moreover the result show the application of higher con- centration of fungicides led to increasing the nutrients imbalance in soy bean.

\section{DISCUSSION}

The data in the present study indicates that the metabolic activities of the mycorrhizal fungus in infected soy bean plants varied with treatments of soil by different fungicides. Differences were reflected in the growth of mycorrhizal plants, nutrients accumulation, nutrient index and nutrients balance index. These results support previous reports on the variation in the toxicity of fungicides to vesicular arbuscular mycorrhiza [22]. The dominance of 
sinoculateted treatments with mycorrhiza for nitrogen, phosphorus, agnesium, iron and total dry weight, this may be due to the fact that the mycorrhiza increase the absorption of phosphorus and other essential elements required for growth these results and explanation are similar with those reported by [23]. Application of the fungicides Prasamid and Antracol relatively enhance the plant to mycorrhizal inoculation these fungicides essentially eliminated or reduced the beneficial effect of mycorrhizal fungus on the growth of plant, macro and micronutrients nutrition, mycorrhizal fungi can be relatively susceptible to certain fungicides particularly when the fungicides is applied to the seeds or into the soil, while other fungicides can stimulate mycorrhiza growth [24]. When Prasamid and Antracol were applied half of the field rate recommended for root diseases control the plant dry matter nutrients content and nutrient balance were significantly increased compared to field rate multiple field rate application. These results are in agreement with those of [25] who reported stimulatory effect of lower concentration of some fungicides on mycorrhizal root colonization and plant dry matter. It is of interest to note that the increases in growth of mycorrhizal plants is not strangely parallel with the concentration of both fungicides, its mean that the dray matter production and nutrients uptake reduce with higher rate application of fungicides, this could be explained on the basis that the fungi toxicity of these fungicides when applied at higher concentration may be injure fungal cell at many site and it is also possible that may inhibited a number of enzymes involved in nutrient assimilation. [6] reported that the application of higher concentration of fungicides affect vesicular arbuscular mycorrhizal primarily by inhibition spore germination and infection processes, also [26]. Their results have indicated that root exudates may be the factors governing mycorrhizal symbiosis, pesticides that increase root exudation may increase mycorrhizal infection. Both experimental factors and their interaction significantly affected soy bean nutrients concentration and nutrients balance index. Inoculation of soybean plants with vesicular arbuscular mycorrhizal fungi was associated with alterations in the contents of nutrients in the shoots. Total nitrogen, phosphorus, magnesium and iron tended to be higher in vesicular arbuscular mycorrhizal-colonized soybean than in non-colonized plants. the total amount of mentioned nutrients accumulation in the shoots of soybean were greater when low concentration of fungicides applied with higher concentration of fungicides there was less mycorrhizal effect on nutrient accumulation. Soya bean plants colonized by vesicular arbuscular mycorrhiza had no significant difference in $\mathrm{Ca}$ and $\mathrm{K}$ content than control, moreover $\mathrm{Ca}$ and $\mathrm{K}$ contents of shoot in mycorrhizal and mycorrhizal plants increase with increasing the concentration of fun- gicides, however the combination between mycorrhiza and fungicides enhance the nutrients balance index in soybean plants. The enhancement of nutrient acquisition by mycorrhizal infection can be attributed to direct hyphal uptake or indirect effects brought about by morphological a physiological changes in the host roots, in addition to that the VAM differs when subjected to different fungicides and some combination of AM and fungicides may be more efficient under certain circumstances. According to our result vesicular arbuscular mycorrhizal inoculation can significantly alleviate the unfavorable effects of fungicides on soybean yield and nutrients balance. These all indicated that how using chemicals, among their other unfavorable effects, particularly on the environments can influence the nutritional quality of the plants [10].

\section{CONCLUSION}

The result of this study concluded that the metabolic activities of the mycorr hizal fungus in infected soy bean plants varied with treatments of soil by different fungicides. Differences were reflected in the growth of mycorrhizal plants, nutrients accumulation, nutrient index and nutrients balance index. These results support previous reports on the variation in the toxicity of fungicides to VA mycorrhiza.

\section{ACKNOWLEDGEMENTS}

Grateful acknowledgement is extended to biology department. College of Scientific Education University of Salahaddin-Hawler for providing laboratory facility.

\section{REFERENCES}

[1] Bethlenfalvay, G.J. and Linderman, R.G. (1992) Preface: Mycorrhizae in sustainable agriculture. ASA Special Publication No. 54. American Society for Agriculture, Madison.

[2] Ocampo, J.A. (1993) Influence of pesticides on VA mycorrhizae. In: Altman, J., Ed., Pesticide Interactions in Crop Production, CRC Press, Boca Raton, 214-226.

[3] Perrin, R. and Plenchette, C. (1993) Effects of some fungicides applied as soil drenches on the mycorrhizal infectivity of two cultivated soils and their receptiveness to Glomus intraradices. Crop Protection, 12, 127-133. doi:10.1016/0261-2194(93)90139-A

[4] Kurle, E.J. and Pfleger, F.L. (1994) The effects of cultural practices and pesticides on VAM fungi. APS Press, St. Paul, 101-131.

[5] Chiocchio, V.N., Venedikian, A.E., Martinez, A., Menendez, J., Ocampo, A. and Godeas, A. (2000) Effect of the fungicide benomyl on spore germination and hyphal length of the arbuscular mycorrhizal fungus Glomus mosseae. International Microbiology, 3, 173-175.

[6] Menge, J.A. (1982) Effect of soil fumigants and fungi- 
cides on vesicular-arbuscular fungi. Phytopathology, 72, 1125-1132.

[7] Salem, S.F., Dobolyi, C., Helyes, L., Pçk, Z. and Dimçny, J. (2003) Side-effect of benomyl and captan on arbuscular mycorrhiza formation in tomato plant. Acta Horticulturae: VIII International Symposium on the Processing Tomato, 613, 243-246.

[8] Kjoller, R. and Rosendahl, S. (2000) Effects of fungicides on arbuscular mycorrhizal fungi differential responses in alkaline phosphatase activity of external and internal hyphae. Biology and Fertility of Soils, 31, 361-365. doi: $10.1007 / \mathrm{s} 003749900180$

[9] Smith, M.D., Hartnett, D.C. and Rice, C.W. (2000) Effects of long term fungicides application on microbial properties in tallg rass prairie soil. Soil Biology \& Biochemistry, 32, 935-946.

[10] Samarbakhsh, S., Rejali, F., Ardakani, M.R., Pak Nejad, F. and Miransari, M. (2009) The combination effects fungicides and arbuscular mycorrhiza on corn (Zea mays L.) growth and yield uder field conditions. Journal of Biological Science, 9, 372-376.

[11] Schreiner, R.P. and Bethlenfalvay, G.J. (1996) Mycorrhizae, biocides, and biocontrol. 4. Response of a mixed culture of arbuscular mycorrhizal fungi and host plant to three fungicides. Biology and Fertility of Soils, 23, 189-195. doi:10.1007/BF00336062

[12] Hamel, C., Furlan, B.V. and Smith, D.L. (1991) $\mathrm{N}_{2}$-fixation and transfer in a field grown mycorrhizal corn and soybean intercrop. Plant and Soil, 133, 177-185. doi:10.1007/BF00009190

[13] Soltanpour, P.N., Malakouti, M.J. and Ronaghi, A. (1995) Comparison of diagnosis and recommendation integrated system and nutrient sufficient range of corn. Soil Science Society of American Journal, 59, 133-139. doi:10.2136/sssaj1995.03615995005900010021x

[14] Cline, R.A. (1962) Sampling techniques for determining leaf nutrient concentrations for strawberries. Annual Report of Vineland Horticultural Experiment Station and Products Laboratory (Ontario), 19-27.

[15] Schuffelen, A.A.M. and Vanschaunouwenburg, J.G.H. (1961) Quick testes for soil and plant analysis used by small laboratories. Netherland Journal of Agriculture
Science, 9, 2-16.

[16] Bremner, J.M. and Mulvaney, C.S. (1982) Methods of soil analysis: Part 2. Chemical and microbiological properties, 2nd Edition. Agronomy, Vol. 9, American Society of Soil Science, Madison, 595-624.

[17] Black, C.A. (1965) Method of soil analysis: Parts (1 and 2). Agronomy Monograph, Vol. 9, American Society of Agronomy Inc. Publishing, Madison, 1-1575.

[18] Allen, S.E. (1976) Chemical analysis of ecological materials. Blackwell Scientific Publications, Oxford, 1-500.

[19] Pansu, M. and Gautheyrou, J. (2006) Hand book of soil analysis. Springer-Verlag, Berlin Heidelberg, 1-993.

[20] Hallmark, W.B., DeMooy, C.J. and Pesek, J. (1987) Comparison of two methods for diagnosing nutrient deficiencies. Journal of Fertilizers Issues, 4, 151-158.

[21] Steele, R.G. and Torrie, J.H. (1969) Principle and procedure of statistic. McGraw Hill Book Co. Inc., New York, $1-530$.

[22] Jabaji-Hare, S.H. and Kendrick, W.B. (1987) Response of an endomycorrhizal fungus in Allium porrum L. to different concentrations of the systemstic fuingicides metalaxyln (Ridomil) and fosetyl-Al (Aliette). Soil Biology \& Biochemistry, 19, 95-99. doi:10.1016/0038-0717(87)90131-3

[23] Mustafa, K.K., Darwesh, D.A. and Luay, A.A. (2004) Effect of mycorrhiza, phosphorus and urea on ammonia volatilization and soybean growth. Journal of Dohuk University, 7, 101-105.

[24] Abdel-fattah, G.M. and Mankarious, A.T. (1997) Differential effects of fungicides on fungal viability and efficiency. Journal of Union Arabic Biology, 3, 237-261.

[25] Mankarios, A.T., Gianinazzi, S. and Abdel El-Fattah, G.M. (1995) Improved growth and nutrition of soybean (Glycine $\max$ L.) in saline soil associated with colonization by vesicular arbascular mycorrhiza fungi. Egyptian Journal of Botany, 35, 101-117.

[26] Ratanayake, M., Leonard, R.T. and Menge, J.A. (1978) Root exudation in relation to supply of phosphorus and its possible relevance to mycorrhizal formation. New Phtology, 81, 543-552. doi:10.1111/j.1469-8137.1978.tb01627.x 